\title{
Evaluation of the Degradation Level of a Fluvial Basin in the Western Area of Côte d'Ivoire: Case of the Cavally River
}

\author{
Kouamé Toto*, N’Zi Konan Gervais, Gooré Bi Gouli \\ Laboratory of Hydrobiology, University Félix Houphouët-Boigny, Abidjan, Côte d'Ivoire \\ Email address: \\ kouametoto@gmail.com (K. Toto) \\ ${ }^{*}$ Corresponding author

\section{To cite this article:} \\ Kouamé Toto, N'Zi Konan Gervais, Gooré Bi Gouli. Evaluation of the Degradation Level of a Fluvial Basin in the Western Area of Côte \\ d'Ivoire: Case of the Cavally River. American Journal of Environmental Protection. Vol. 10, No. 5, 2021, pp. 111-119. \\ doi: 10.11648/j.ajep.20211005.12
}

Received: October 2, 2021; Accepted: November 2, 2021; Published: November 3, 2021

\begin{abstract}
The present study is a diagnosis of the level of degradation of Cavally River in Côte d'Ivoire. Several abiotic indicators such as physico-chemical parameters were appreciated. These abiotic indicators were supported by biotic indicators sensitive to some variations in quality of water. That is the use of benthic macro-invertebrates as some species of freshwater shrimps of the genus Macrobrachium. Sampling was made between September 2015 and August 2016 on the upper course of Cavally River and the area on either side of the mining zone "Ity". Measures of physico-chemical parameters such as dissolved oxygen, temperature of water, hydrogen potential, electrical conductivity, mercury rate and water transparency were made by season using multi parameters. Shrimps were caught monthly using dip nets and keep nets. The extreme value of physicochemical parameters is for dissolved oxygen value were $4.90 \mathrm{mg} / 1$, temperature of water $\left(25.55^{\circ} \mathrm{C}\right)$, hydrogen potential (8.48), electrical conductivity $(53.14 \mu \mathrm{S} / \mathrm{cm})$, mercury rate $\left(5.75 .10^{-3} \mathrm{mg} / \mathrm{kg}\right)$ and water transparency $(27.06 \mathrm{~cm})$. In general, the results showed that the extreme values of physico-chemical parameters were recorded in areas with high concentrations of anthropogenic activities. In the mining areas, high levels of mercury have been recorded above those of the WHO guideline for surface water. In total, M. vollenhovenii was the most abundant species with 383 individuals out of 879 specimens caught (43.57\%). It is followed by $M$. dux with 321 individuals (36.51\%) and M. macrobrachion with an abundance of 175 individuals (19.90\%). Spatially, these species have been more abundant in the upstream and downstream areas which are more or less conserved environments. However, they were less abundant in mining areas. These results show that the upper course of the Cavally River is deteriorating. That constitutes a real threat to aquatic organisms and biodiversity.
\end{abstract}

Keywords: Population Pressure, Environmental Level Degradation, Freshwater Shrimps, Physico-chemical Parameters, Cavally River, Côte d'Ivoire

\section{Introduction}

Shrimps are among the fishery resources that undeniably have a socio-economic importance for the populations $[13,5$, $12,25,7,4,40,26]$. They are exploited all over the world in order to address protein supply needs. This activity generates jobs and incomes for people $[17,3]$. In their respective habitats, shrimps are involved in the balance of ecosystems $[14,27,22]$. Indeed, they are prey for a majority of aquatic species such as Mormyrops anguilloides [43]. Among shrimps, some species such as Macrobrachium vollenhovenii, M. macrobrachion and $M$. $d u x$ are excellent indicators of healthy environments [9]. Cavally River, one of the four major rivers that cross Côte d'Ivoire, is a living place of many fauna species including the three previous shrimp species. Since the military-political crisis of 2002 [20], this hydrosystem is likely under the threat of unorganized and anarchic mining $[34,11]$ that could impact, like all other anthropogenic activities, the diversity and distribution of aquatic organisms $[17,39,8]$. These three species of shrimps are well known and insufficiently harversted in Côte d'Ivoire $[3,17]$ and particularly in Cavally. However, in recent years, their stocks are decreasing because of the degradation of their respective habitats linked to human activities. Moreover, the disappearance of the species thus exploited could seriously 
disturb the environmental, social and economic balance in areas of exploitation. Thus, this current work, aims to assess the level of degradation of Cavally River upper course through the study of physico-chemical parameters and biological indicators in order to help safeguard biodiversity and contribute to sustainable development.

\section{Materials and Methods}

The Cavally is a River in West Africa running from north of Mont Nimba in Guinea at an altitude of $600 \mathrm{~m}$, through Côte d'Ivoire, to Zwedru in Liberia, and back to the border with Côte d'Ivoire. It forms the southern two-thirds of the international boundary between Liberia and Côte d'Ivoire [15]. Long of $700 \mathrm{~km}$, its catchment area is $30600 \mathrm{~km}^{2}$. The Ivorian part of the Cavally River is $515 \mathrm{~km}$ long with a catchment area of $15000 \mathrm{~km}^{2}$.

Four sampling stations were selected on the Cavally River and its tributaries on both sides of the industrial and mining zone "Ity": one station $\mathrm{Z} 1\left(7^{\circ} 05^{\prime} 43.0^{\prime \prime} \mathrm{N}-8^{\circ} 06^{\prime} 28.4^{\prime \prime} \mathrm{W}\right)$ is an upstream; one station Z2 $\left(6^{\circ} 52^{\prime} 33.52^{\prime \prime} \mathrm{N}\right.$ $\left.8^{\circ} 06^{\prime} 29.21^{\prime \prime} \mathrm{W}\right)$ an intermediate stream and two stations [Z3 $\left(6^{\circ} 50^{\prime} 30.12^{\prime \prime} \mathrm{N}-8^{\circ} 06^{\prime} 59.03^{\prime \prime} \mathrm{W}\right)$ and $\mathrm{Z} 4\left(6^{\circ} 40^{\prime} 22.1^{\prime \prime} \mathrm{N}\right.$ $\left.\left.8^{\circ} 16^{\prime} 18.9^{\prime \prime} \mathrm{W}\right)\right]$ in downstream (Figure 1). The choice of stations was made to measure impact of the "Ity" gold mine operation on shrimps population and the environment of the area.

Measure of environmental variables: Physico-chemical parameters were measured in situ by season from september 2015 to august 2016 in the four stations. The temperature of water (in ${ }^{\circ} \mathrm{C}$ ), the hydrogen potential, the conductivity (in $\mu \mathrm{S} / \mathrm{cm}$ ) and the rate of dissolved oxygen (in $\mathrm{mg} / \mathrm{l}$ ), were measured using multi-parameters model HQ 40d and HANNA. In addition to these devices, a Secchi disc of diameter $30 \mathrm{~cm}$ painted into white-black was used to estimate, in centimeters, transparency.

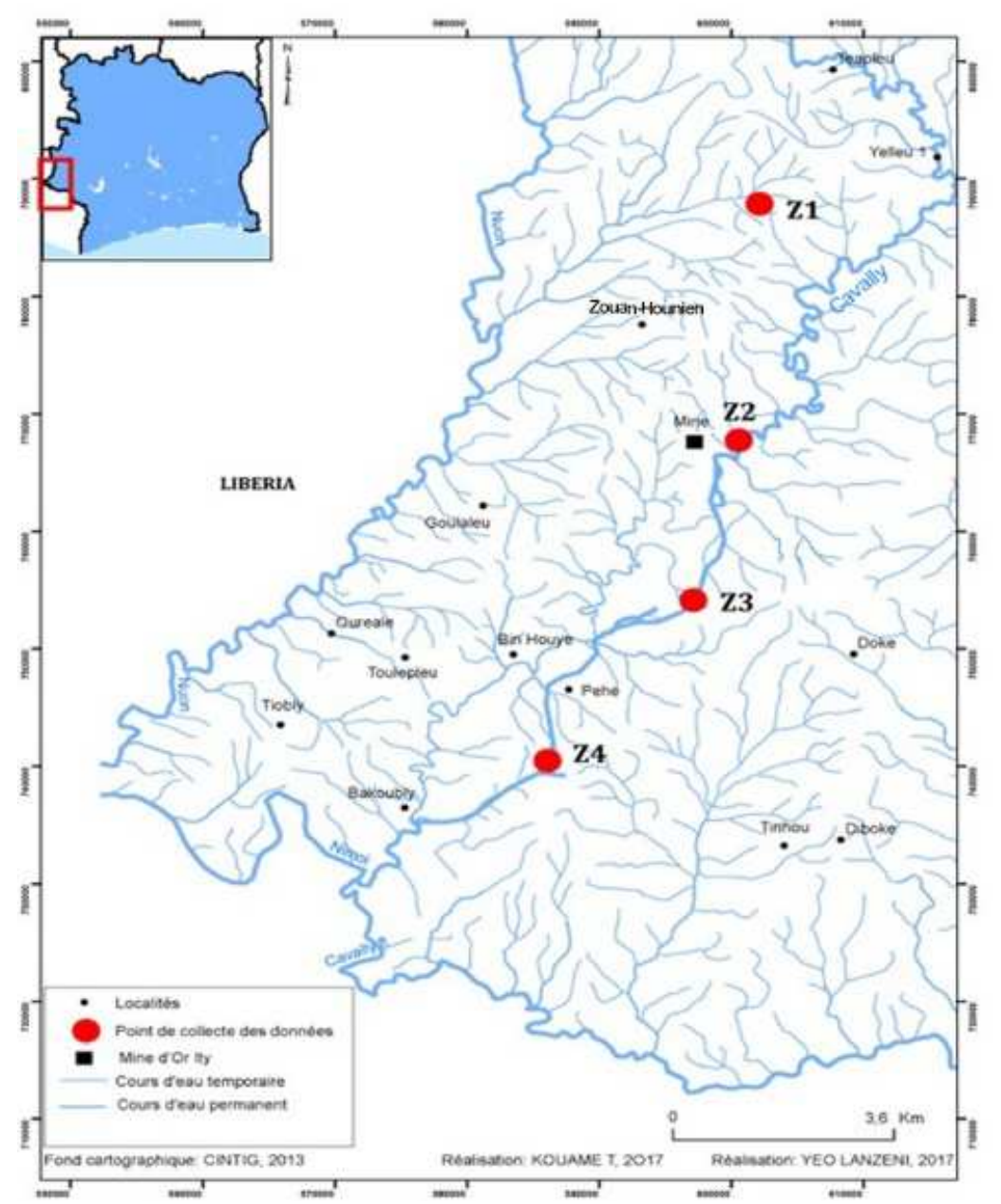

Figure 1. Stations sampled (•) and mining zone "Ity” (ロ) in the upper Cavally River (Cote d'Ivoire) from September 2015 to August 2016.

Shrimps sampling and identification: Shrimps were sampled monthly from September 2015 to August 2016 using a dip net $(25 \mathrm{~cm}$ opening diameter and $2 \mathrm{~mm}$ mesh size). Fishing is done by one person according to Djiriéoulou [8]. The dip net is immersed in water and then removed after a period of time sufficient to optimize shrimp capture. At each site, the same catch effort (15 min of fishing) was applied. Shrimps captured were conserved into formaldehyde $10 \%$ and transported to the laboratory for identification and dissection. Shrimps were identified according to Monod [28], Monod [29], Gooré and al. [18] and Konan [22] identification keys. At each site, shrimp samples were 
collected and kept cool for the dose of mercury rate by absorption spectrophotometer in $\mathrm{mg} / \mathrm{kg}$.

Data Analysis: The percentage of occurrence was used to determine shrimps population dynamics. The percentage of occurrence is defined by the following formula: $\mathrm{F}=(\mathrm{pi} / \mathrm{P})$ $\times 100, \mathrm{pi}=$ number of samples where species $\mathrm{i}$ appears and $\mathrm{P}$ $=$ total number of samples in a place. The classification of taxa based on their percentage of occurrence was done according to Dajoz [6]: $\% \mathrm{~F} \geq 50$ : constant taxon; $25 \leq \% \mathrm{~F}<$ 50: accessory taxon and $\% \mathrm{~F}<25$ : accidental taxon. KruskalWallis test is a nonparametric test which is used to compare the spatial variation of the physicochemical parameters. Spearman correlation test was used to analyze the relationship between species abundance and environmental variables.

\section{Results}

\subsection{Anthropic Pressures}

Human influence is particularly important in many villages near the Cavally River. These human activities are agriculture, artisanal and illegal goldmining, and industrial gold mining which are the basis of the socio-economic development of the area (Figures 2, 3 and 4). The indigenous (Yacoubas and Guérés), non-indigenous (Baoulé, Malinké, Sénoufo etc.) and even foreign populations (Liberians, Burkinabés, Guineans, Ghanaians, Malians, etc.) living in these localities, directly or indirectly, dependent on the resources of the Cavally River.

The aboriginal communities (Yacouba and Guérés ethnic group), the non-indigenous (Baoulé, Malinké, Sénoufo and even foreign populations such as Liberians, Burkinabes, Guineans, Ghanaians, Malians, living in these localities directly dependent on the Cavally River. They use as drinking water, laundry, bath and also consume species caught in this stream. Also, these populations directly and indirectly put some substances such as soaps, fertilizers and pesticides, mercury in the river, generate thus pollutants in the Cavally River.

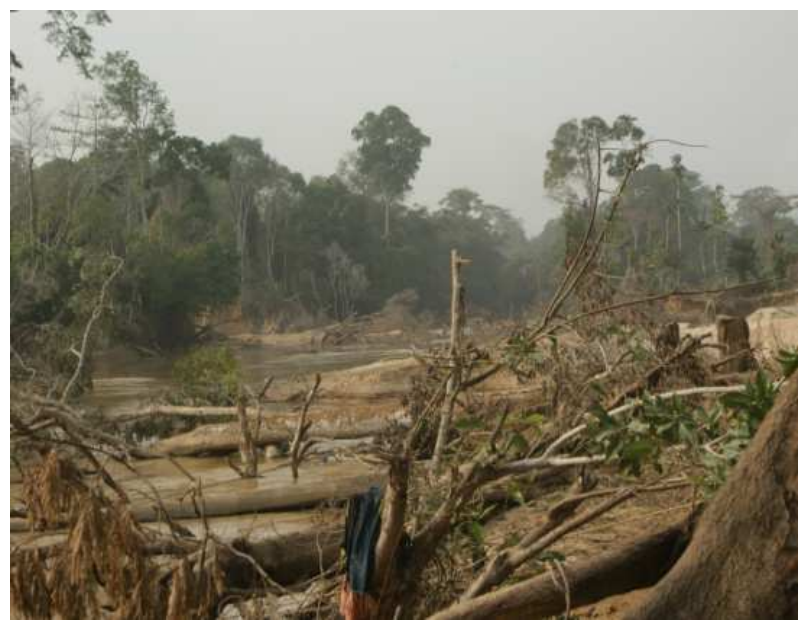

Figure 2. View of the vegetable destruction by miners on the Cavally River in Floleu station.

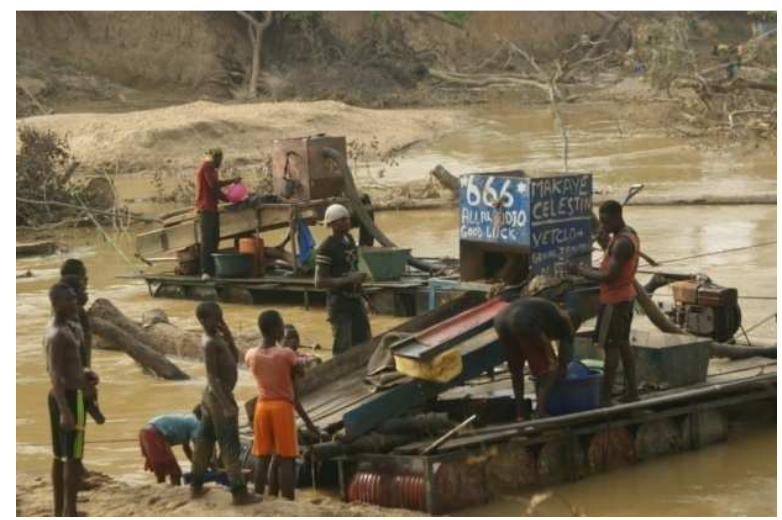

Figure 3. Clandestine mining unit in Floleu Station (Z3).

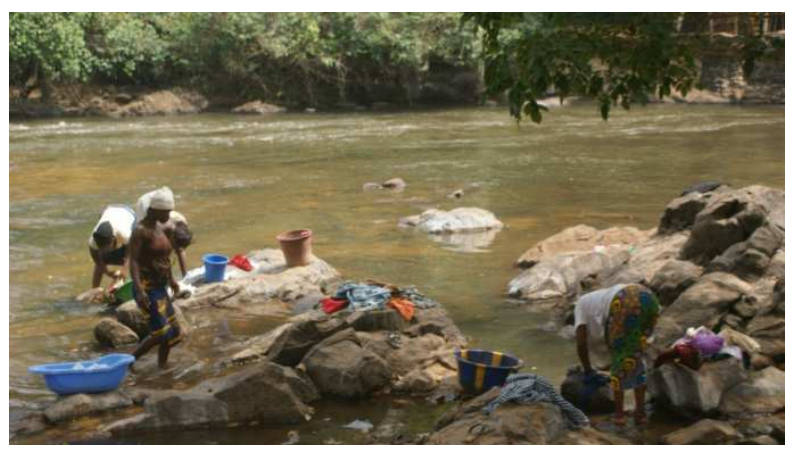

Figure 4. Partial view of laundry site at Lieupleu station (Z1) in the Cavally River.

\subsection{Characteristics of the Upper Course of Cavally}

\section{Spatial variations of physico-chemical parameters}

The annual overall median of dissolved oxygen rates recorded at all stations in the upper course of Cavally River is $6.65 \mathrm{mg} / \mathrm{l}$. The median of this lowest parameter $(4.90 \mathrm{mg} / \mathrm{l})$ was obtained in the station Z3 in locality of Floleu. The highest rate $(7.44 \mathrm{mg} / \mathrm{l})$ is obtained in the station $\mathrm{Z1}$ in locality of Lieupleu. Statistical analysis of the variation of this parameter showed no difference between the stations (Kruskal-Wallis test, $\mathrm{p}=0.38>0.05$ ) (Figure 5).

Regarding the $\mathrm{pH}$, in all stations the annual overall median of $\mathrm{pH}$ values at all stations is 7.77 . The lowest median (6.81) was obtained in station Z4 in the locality of Glareu which is acidic. The highest (8.48) was obtained in station $\mathrm{Z1}$ which is the most alkaline $\mathrm{pH}$. The Kruskal-Wallis test showed a significant difference between the stations $Z 1$ and Z2; Z1 and $\mathrm{Z4}$; $\mathrm{Z3}$ and $\mathrm{Z4}$ at $\mathrm{p}=0.007<0.05$.

Concerning the water temperature, the annual overall median of the temperatures determined for all stations is $25.02^{\circ} \mathrm{C}$. The lowest median $\left(23.53^{\circ} \mathrm{C}\right)$ was obtained in station $\mathrm{Z} 1$ and the highest $\left(25.55^{\circ} \mathrm{C}\right)$ was obtained in station Z3. Statistical analysis of the median variance comparison showed no difference between the different sampling stations (Kruskal-Wallis test, $\mathrm{p}=0.09>0.05$ ).

The annual overall median of the conductivities determined on all the stations is $47.5 \mu \mathrm{S} / \mathrm{cm}$. The lowest median $(46.43$ $\mu \mathrm{S} / \mathrm{cm})$ was obtained in station $\mathrm{Z2}$ and the highest $(53.14$ $\mu \mathrm{S} / \mathrm{cm}$ ) was obtained in station Z3. The Kruskal-Wallis test showed no significant difference between the different 
sampling stations (Kruskal-Wallis test, $\mathrm{p}=0.57>0.05$ ).

For mercury, the annual overall median of mercury levels determined for all stations is $0.79 .10^{-3} \mathrm{mg} / \mathrm{kg}$. The lowest median $\left(0.475 .10^{-3} \mathrm{mg} / \mathrm{kg}\right)$ of this parameter was determined in station $\mathrm{Z1}$ while the highest $\left(5.75 .10^{-3} \mathrm{mg} / \mathrm{kg}\right)$ was obtained in station Z3. The results of the Kruskal-Wallis test show that mercury has significantly different values between $\mathrm{Z1}$ and $\mathrm{Z} 2 ; \mathrm{Z1}$ and $\mathrm{Z3} ; \mathrm{Z1}$ and Z4; Z2 and Z3; Z2 and Z4
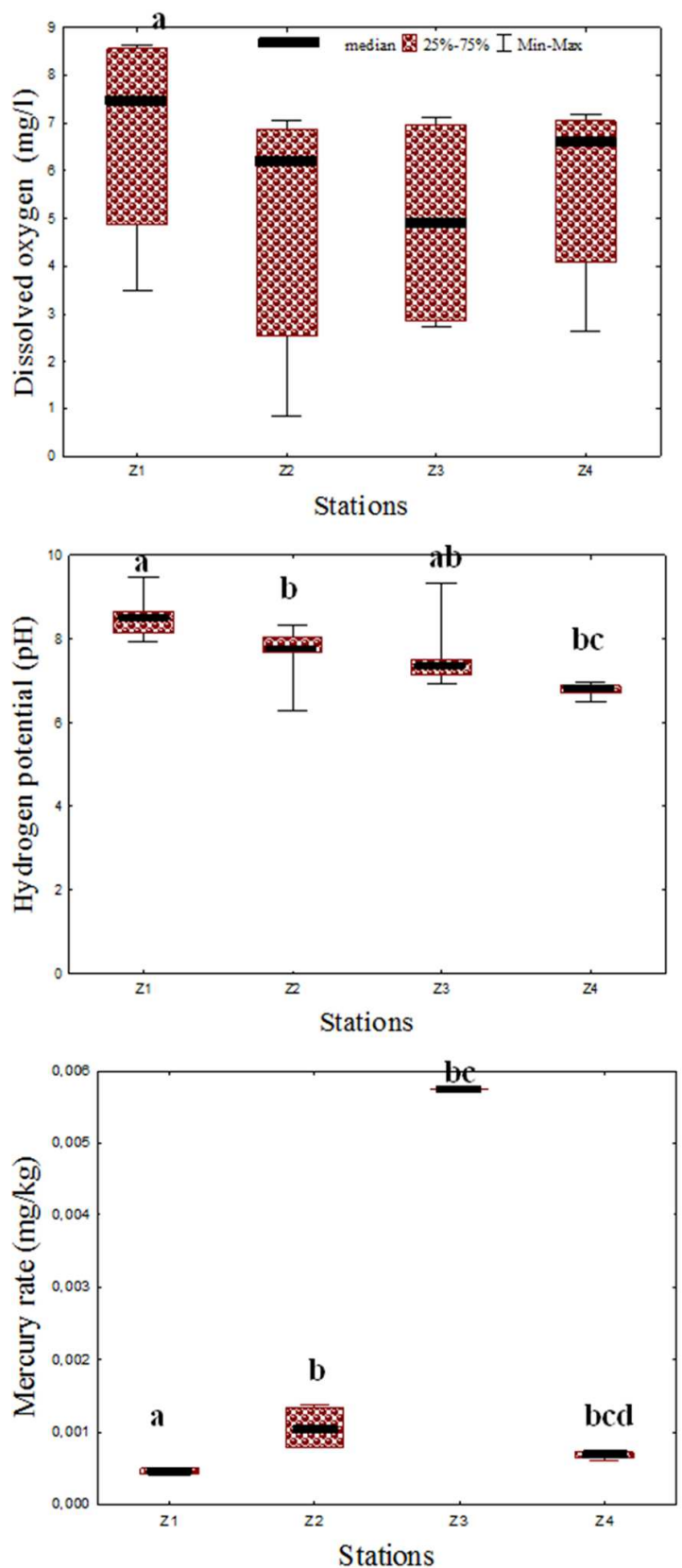

then $\mathrm{Z3}$ and $\mathrm{Z4}(\mathrm{p}=0.002<0.05)$.

With respect to transparency, the annual overall median of the transparency determined for all stations is $34.63 \mathrm{~cm}$. The lowest median value $(27.06 \mathrm{~cm})$ was determined in station $\mathrm{Z2}$ and the highest $(83.52 \mathrm{~cm})$ was determined in station $\mathrm{Z1}$. The results of the analysis of the median variance showed no significant difference between the sampling stations (Kruskal-Wallis test, $\mathrm{p}=0.84>0.05$ ).
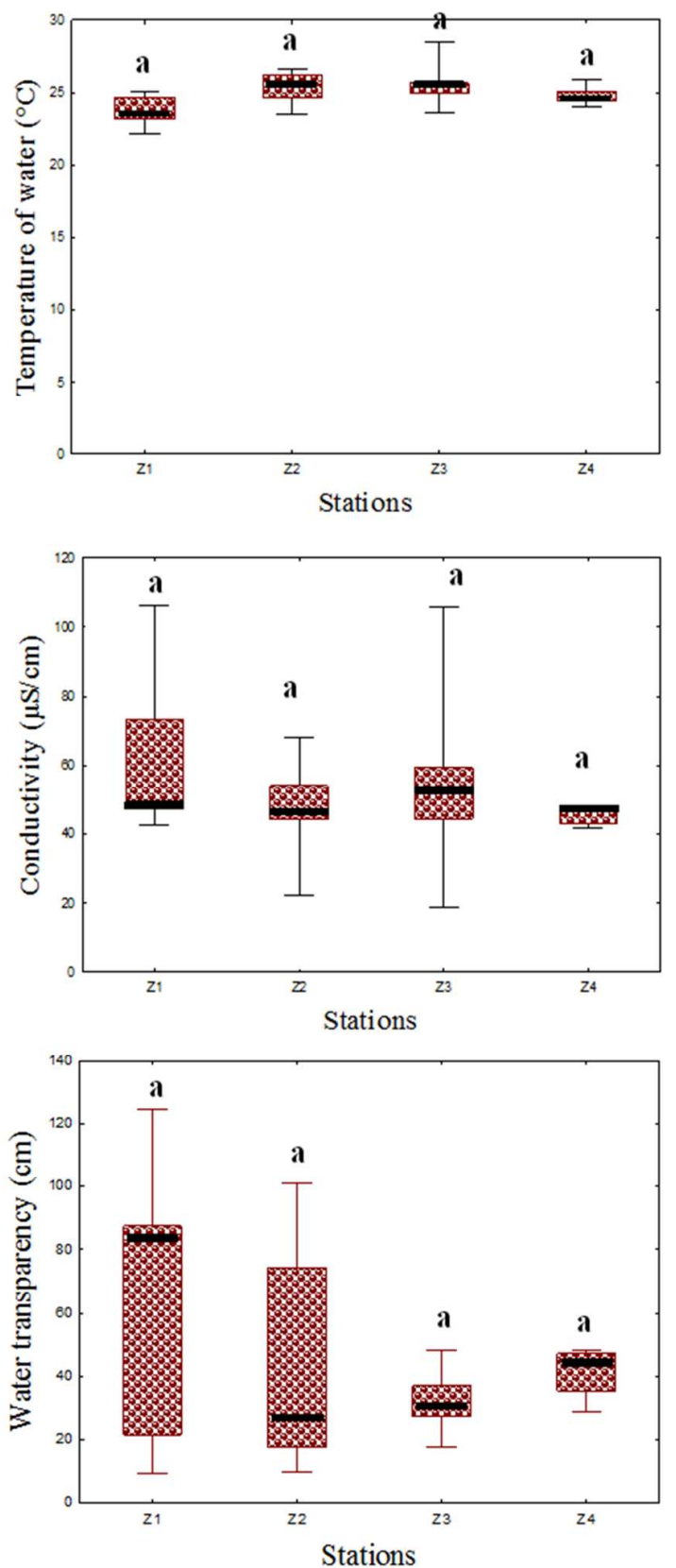

Figure 5. Spatial variations of annual average values of the physico-chemical parameters measured in different stations of the upper course of Cavally River between September 2015 and August 2016. Z1 = Lieupleu; Z2 = Ity; Z3 = Floleu and Z4 = Glareu. Median values with a letter (a, $\boldsymbol{b}$ or $\boldsymbol{c}$ ) in common did not differ significantly (Kruskal-Wallis test, $p>0.05$ ).

\subsection{Biological Inventory and Abundance of Shrimps}

The percentage of occurrence of species differed according to the sampled stations. The species Macrobrachium dux and
M. macrobrachion are constant in the stations $\mathrm{Z} 1$ and $\mathrm{Z} 4$. In station $\mathrm{Z1}$, both species are present with an occurrence of $60 \%$. In station Z4, M. dux is present with an occurrence of $80 \%$ while $M$. macrobrachion is present with a occurrence of $60 \%$. Macrobrachium vollenhovenii is constant at all stations 
except in station $\mathrm{Z3}$ where it is accidental $(\mathrm{F}=40 \%)$. Its occurrence in stations $\mathrm{Z1}$ and $\mathrm{Z} 4$ is $60 \%$ while it is $50 \%$ in station $\mathrm{Z2}$.

To scale of all stations sampled in the upper course of Cavally River, $M$. vollenhovenii is the most abundant species with 383 individuals out of 879 specimens caught and represented $43.57 \%$ of total specimens. It is followed by $M$. dux with 321 individuals (36.51\%) and M. macrobrachion with an abundance of 175 individuals (19.90\%).

According each station, analysis of shrimps abundance showed that in station Z1, Macrobrachium vollenhovenii with $34.04 \%$ is the most abundant species caught. It is followed by $M$. dux with $33.33 \%$ and $M$. macrobrachion with $32.63 \%$. In station Z2, Macrobrachium vollenhovenii with $82.64 \%$ is the most abundant species caught. It is followed by
M. dux with $13.19 \%$ and M. macrobrachion with $4.17 \%$. In station Z3, the lowest abundances were recorded for these three species $M$. vollenhovenii, M. macrobrachion and $M$. $d u x$ respectively $(93.33 \% ; 6.67 \%$ and $0 \%$ individuals). In station Z4, Macrobrachium dux is represented by $49.17 \%$ of relative abundance. It is followed by $M$. vollenhovenii with $33.1 \%$ and $M$. macrobrachion with $17.73 \%$ (Figure 6).

\subsection{Correlation Shrimps Abundance - Stations}

The abundance of M. macrobrachion is positively correlated with dissolved oxygen and transparency, but negatively with mercury rates. Macrobrachium $d u x$ is negatively correlated with water temperature and mercury rates (Table 1).

Table 1. Results of Spearman's correlation analysis (p-values) between shrimp species and environmental variables in the upper course of Cavally River from September 2015 to August 2016. Oxy = oxygen, $T=$ temperature, Cnd = conductivity, Transp = transparency and Merc $=$ mercure.

\begin{tabular}{|c|c|c|c|c|c|c|}
\hline & \multicolumn{6}{|c|}{ Environmental variables } \\
\hline & Oxy & pH & $\mathbf{T}^{\circ}$ eau & Cnd & Transp & Merc \\
\hline Macrobrachium dux & 0.16 & -0.1 & $-0.36^{*}$ & 0.04 & 0.28 & $-0.38 *$ \\
\hline Macrobrachium macrobrachion & $0.38 *$ & 0.1 & -0.27 & 0.02 & $0.35 *$ & $-0.47 *$ \\
\hline Macrobrachium vollenhovenii & -0.04 & -0.04 & -0.2 & -0.24 & 0.25 & -0.07 \\
\hline
\end{tabular}

(*) Significant correlation.

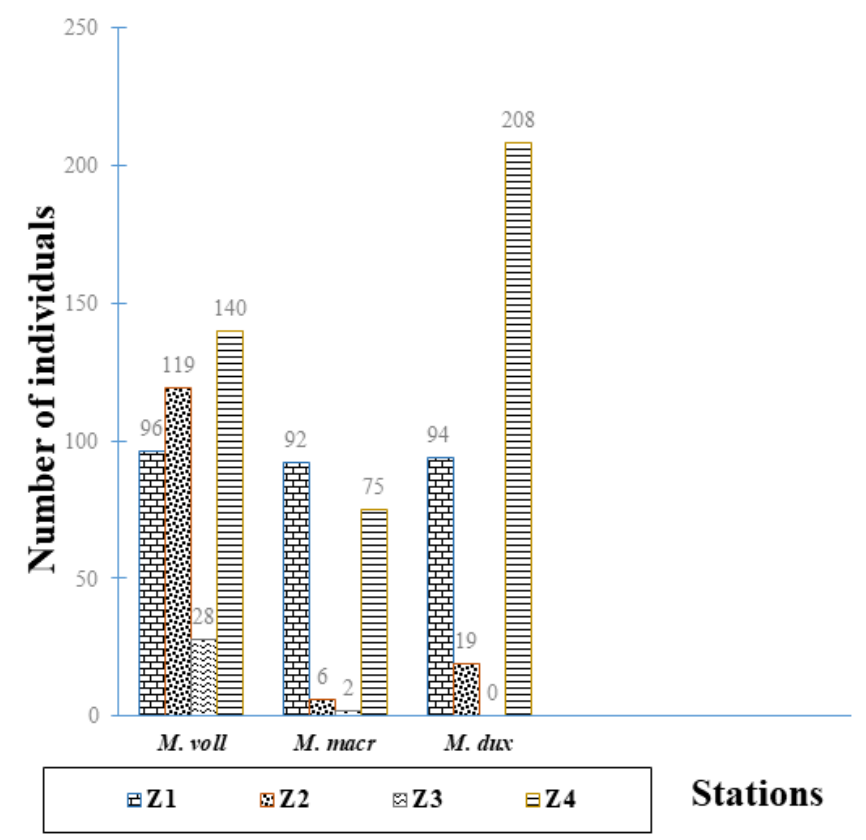

Figure 6. Abundance of shrimp species in different sampling stations in the upper course of Cavally River from September 2015 to August 2016. M. voll $=$ Macrobrachium vollenhovenii and $M$. macr = Macrobrachium macrobrachion.

\section{Discussion}

\subsection{Temperature}

The annual overall median of the temperatures determined for all stations is $25.02^{\circ} \mathrm{C}$. This value is low compared to the average temperature of ivorian rivers which according to Iltis and Lévêque [19] is $28^{\circ} \mathrm{C}$. According to these authors this temperature rarely falls below $25^{\circ} \mathrm{C}$ as it is the case in this study.

In addition, the annual overall median of the temperatures in the upper course of Cavally is superior to that recorded by $\mathrm{N}^{\prime} \mathrm{Zi}$ [32] in the basin of Comoe River $\left(24.93^{\circ} \mathrm{C}\right)$. But it is lower than those recorded by N'Zi [32], Aboua [1] and Boguhé [3] in the basin of Bandama River $\left(28.35^{\circ} \mathrm{C}, 27.60^{\circ} \mathrm{C}\right.$ and $28.07^{\circ} \mathrm{C}$ ) and N'Zi [32] in the basin of Sassandra River $\left(27.08^{\circ} \mathrm{C}\right)$ in Côte d'Ivoire. This difference in temperature observed in the upper course of Cavally River compared with other major rivers of Côte d'Ivoire may be due to the particular climatic conditions (mountain climate) of this area. These same observations were made by Girard and al. [16] who showed that the temperature of the basin of Cavally is relatively low. In addition, according to Welcomme [42], the factors that determine the change of temperature of water in ecosystems are latitude, degree of sunshine, substrate composition, precipitation, wind and vegetation cover.

The annual overall median of the temperatures of the upper course of Cavally is still lower than those measured elsewhere in other hydrosystems in the country [32, 2, 30, 8].

Concerning spatial variation, the lowest values were recorded in stations $Z 1$ and $Z 4$ and the highest in stations $Z 2$ and Z3. Z1 and Z4 which are zones upstream and downstream of the mining zone and therefore far from the mining zone. In $\mathrm{Z} 2$ and $\mathrm{Z} 3$, mining is self-evident with the destruction of vegetation cover. This leads to a reduction or suppression of the canopy as reported by Djiriéoulou [8]. This exposes the river to solar radiation thus causing a rise in the temperature of the water. In stations $\mathrm{Z1}$ and $\mathrm{Z4}$, the presence of the canopy and aquatic plants could explain the decrease in temperature. In addition to these factors, the station of Lieupleu (Z1) benefits a fast water flow rates, 
allowing a continual renewal of the water and a decrease of its temperature.

$p H$

The annual overall median of $\mathrm{pH}$ values measured in the upper course of the Cavally River is weakly basic $(\mathrm{pH}=7.77)$ that is to say, it is slightly above neutral $(\mathrm{pH}=7)$. These results indicate that the aquatic environment of the Upper course of Cavally River is generally in good condition. In general, trends in the annual overall median of $\mathrm{pH}$ values show that the $\mathrm{pH}$ measured in the upper course of Cavally is near to that of raw water. Webber and Stumm [41] state that these values are between 6.5 and 8.5.

While comparing the previous results of the Cavally River $\mathrm{pH}$ with other large basins of Côte d'Ivoire, $\mathrm{pH}$ of Cavally River is low compared to the average values obtained by N'Zi [32] in Sassandra (average $\mathrm{pH}=9.25$; $\mathrm{pH}$ extreme values between 11.28 and 5.08) and the Bandama (average: 9.62; extreme values: 11.79 and 5.08).

However, the annual values measured in Comoe basin (average: 6.33; extreme values: 7.43 and 4) by N'Zi [32] and by Yao [43] (extreme values: 7.43 and 5.00), are acidic. They are therefore different from those obtained in the upper course of the Cavally River. The $\mathrm{pH}$ of the water in the basins of Côte d'Ivoire is increasing from east to west. This situation can be explained by the interactions between the nature of the substrates (ferruginous soils, ferrisols, ferralitic soils, etc.) and the types of existing vegetation (savannas and forests). According to N'Douba [31], the $\mathrm{pH}$ is influenced on a daily by the biological and geological processes occurring in the water, and by the nature of the lands crossed.

The maximum median value $((8.48)$ of the $\mathrm{pH}$ was obtained at the Lieupleu station (Z1). This high $\mathrm{pH}$ compared with the other stations in the study is probably due to the frequent use of sodium hypochloryte and other esterifying products during laundry and sometimes in shallower rocky areas of the river.

The $\mathrm{Z} 2$ and $\mathrm{Z} 3$ stations receive discharges from artisanal gold mining and illegal mining activities, as well as effluent from the Ity gold mine. To these discharges are added those of organic fertilizers, especially compost, for coffee and cocoa fields. All these activities amplify this process of natural acidification which was above all a biological and geological phenomenon of the environment. These processes are strongly affected by the temperature of the water which is raised in these stations [1].

\subsection{Dissolve Oxygen}

The annual overall median of dissolved oxygen rates recorded at all stations in the upper course of Cavally River is $6.65 \mathrm{mg} / \mathrm{l}$. A stream with a dissolved oxygen rate between 4 and $6 \mathrm{mg} / 1$ with a temperature of between 20 and $25^{\circ} \mathrm{C}$ is classified as good quality according to Painchaud [36]. The annual overall median of dissolved oxygen rates of Cavally River is near to that of Painchaud [36]. Moreover that value is comparable to those obtained by Kamelan [21] in the waters of Tai National Park. This author obtained values ranging between $4.57 \pm 1.52 \mathrm{mg} / \mathrm{l}$ and $7.45 \pm 1.52 \mathrm{mg} / \mathrm{l}$.
According to Painchaud [36], we can say that the upper course of Cavally still benefits of the good oxygenation.

Spatially, Stations of Lieupleu (Z1) and Glareu (Z4) have relatively high oxygen rate compared to stations of Ity (Z2) and Floleu (Z3). These last two stations are located in the mining environment. The less oxygenated $(4.90 \mathrm{mg} / \mathrm{l})$ and relatively warm $\left(25.55^{\circ} \mathrm{C}\right)$ waters, were observed in stations where anthropogenic activities were very high such as Floreu (Z3) and Ity (Z2). However, waters which are more oxygenated $(7.44 \mathrm{mg} / \mathrm{l})$ and relatively cold $\left(23.53^{\circ} \mathrm{C}\right)$ have been observed in stations where there are very few human activities including in $\mathrm{Z1}$. The reduction of oxygen can be explained by the destruction of the canopy. Indeed, the presence of the canopy participates in the oxygenation of the watercourse thanks to the phenomenon of photosynthesis. This contribution of photosynthesis to the regeneration of oxygen has been mentioned by Environnement Canada [10]. According to this author, this phenomenon is part of biochemical processes provided by plants that produce oxygen during the day (photosynthesis) and consume it during the night (oxidative respiration). Moreover, according to $\mathrm{N}$ ' $\mathrm{Zi}$ [32], the decrease in oxygen rate is partly due to human activities.

\subsection{Conductivity}

The annual overall median of the conductivities determined on all the stations is $47.5 \mu \mathrm{S} / \mathrm{cm}$. That value show that water of the basin of the Cavally River is weakly mineralized and therefore conducts the electric current weakly. Therefore, the water of the upper course of Cavally is very soft. These values are very close to those measured by Kamelan [21] who obtained values fluctuating between 39.25 $\pm 6.71 \mu \mathrm{S} / \mathrm{cm}$ and $62.80 \pm 15.84 \mu \mathrm{S} / \mathrm{cm}$ in the Tai National Park (World Heritage of UNESCO since 1982). This shows that the upper course of Cavally is presumably preserved.

To scale the stations, the conductivity seems to be diminished from upstream to downstream along the watercourse. This result is contrary to that observed in the N'Zi, tributary of Bandama River, in Côte d'Ivoire by Iltis and Lévêque [19] who noted a significant increase of conductivity from upstream to downstream. The irregularity of flows could explain this variation [24]. Indeed, the speed of the water current being greater in upstream at station Z1, generates particles in suspension by the brewing phenomenon. The increase of these particles can explain the increase of the conductivity contrary to the part situated downstream at Glareu station where the speed of the current is relatively low.

Its highest value of conductivity was observed at Lieupleu in station $\mathrm{Z} 1$ in upstream and the lowest in station Z2. In upstream, high conductivity value could be justified by the existence of a bedrock abundant in $\mathrm{Z} 1$. Indeed, more recent studies conducted by Parizot [37] have shown that the water conductivity is partly related to the water-rock interactions and the water's ability to dissolve the minerals contained in the rocks. At Floleu station (Z3), this gradient is not respected and high conductivity values have been recorded 
( $53.14 \mu \mathrm{S} / \mathrm{cm})$. This characteristic observed in $\mathrm{Z3}$ could be due to the influence of the highly developed mining and correlated with the use of mercury for the treatment of gold.

\subsection{Mercury}

The annual overall median of mercury levels determined for all stations is $0.79 .10^{-3} \mathrm{mg} / \mathrm{kg}$.

Highly values of this parameter were found respectively in the mining areas at Ity (Z2) and Floleu (Z3). The highest value $\left(5.75 .10^{-3} \mathrm{mg} / \mathrm{kg}\right)$ was obtained in station $Z 3$. The highest concentrations found in these two stations could be explained by intensive mining activities. The mercury values recorded in the mining exploitation zones (Ity and Floleu) are above the WHO guideline for surface water [35] which specified that an environment is of good quality when the mercury rate $(\mathrm{Hg})$ is less than $0.001 \mathrm{mg} / \mathrm{kg}$. This fact indicates that the mining zones are contaminated and confirm the gravity of the degradation under way.

\subsection{Transparency}

The annual overall median of the transparency determined for all stations is $34.63 \mathrm{~cm}$. The lowest median value $(27.06$ $\mathrm{cm})$ was determined in station $\mathrm{Z} 2$ and the highest $(83.52 \mathrm{~cm})$ was determined in station $\mathrm{Z1}$. The high value of the transparency in Z1 means that the Cavally water in this station of the upper course is clearer. The low values obtained in $\mathrm{Z} 2$ could be due to the concentration of human activities in this zone.

The annual overall median values of Cavally transparency are low compared to those obtained by N'Zi [32] in other large basins of Côte d'Ivoire. This author obtained respectively for Comoe River (average transparency $=55.48$ $\mathrm{cm}$ with extreme values between 110.00 and $5.00 \mathrm{~cm}$ ), Bandama River (average: $52.65 \mathrm{~cm}$, extreme values: 100.00 and $10.00 \mathrm{~cm}$ ) and Sassandra River (average: $59.66 \mathrm{~cm}$, extreme values: 158.00 and $10.00 \mathrm{~cm}$ ). These low values of transparency obtained in Cavally River could be explained by the frequency and abundance of rainfall in the sampling area. Indeed, the study environment is under the influence of the equatorial mountain climate which is marked by two seasons, a long rainy season from March to October and a short dry season from November to February. The resulting annual runoff of water constantly causes organic materials to flow into the waters of the basin, thus curbing the penetration of sunlight into the deep layers. This phenomenon of runoff of rainwater reducing clarity in rivers has been reported by N'Da [30] in the Bagoe River in Côte d'Ivoire.

\subsection{Correlation Shrimps Abundance - Environment Variables and Stations}

According to biotic factors, the results obtained show that abundance of shrimps is more in upstream at Lieupleu station (Z1) and downstream at Glareu station (Z4) and less the mining stations $Z 2$ and $Z 3$. This difference in abundance could be explained by the fact that the Ity station (Z2) receives mainly treated effluent from the gold mine, and the Floleu station (Z3) has suffered the effects of the mining industry and those of artisanal gold mining. In mining stations, Macrobrachium vollenhovenii is more abundance than other species. This could suggest that this species is more resistant and better adapted to environmental disturbances.

A similar finding was respectively made by Kouamélan and al. [23], N'Zi and al. [33], Yao and al. [44] and Aboua [1] on Boubo River, Comoe and Bandama Rivers. According to those authors, irregular distributions in these rivers are due to human activities.

Analysis of the correlation between shrimps abundance and environmental characteristics showed that dissolved oxygen, $\mathrm{pH}$, water temperature, conductivity, mercury rate and transparency influence species abundance. The abundance of Macrobrachium vollenhovenii, $M$. macrobrachion and $M$. dux was negatively influenced by the mercury rate in $\mathrm{Z3}$ where the lowest abundances were obtained. This influence is more serious for the last two species. Macrobrachium vollenhovenii seems to be the only species able to withstand this relatively high concentration of mercury in the environment. In addition, the absence of $M$. $d u x$ in $\mathrm{Z3}$ could be explained by the too high values of physico-chimical parameters in mining area. Macrobrachium macrobrachion prefers well oxygenated and transparent waters, hence its high abundance in Z1 and Z4.

\section{Conclusion}

The study of the environmental characteristics of the upper course of Cavally River has given annual median values of physico-chemical parameters close to those of raw water. These values are relatively optimal compared to those of international standards except for mercury. The annual average value obtained is critical and indicates that the study environment is contaminated. From the spatial standpoint, the results showed that the extreme values of these parameters characterize highly anthropised environments, particularly the mining areas. The study of spatial abundance of species revealed that shrimps are less abundant in mining areas. Macrobrachium $d u x$ is more susceptible than $M$. vollenhovenii and M. macrobrachion because it has been rare in the critical area of the mining. Ultimately, it can be said that the Cavally River is under threat from human activities. Urgent protection and conservation measures should be considered for safeguarding the biodiversity of this hydro system because artisanal gold mining communities trained and equipped with technologies to reduce health and environment exposure to mercury.

\section{Acknowledgements}

This work was carried out as part of a research project entitled "Contribution to the knowledge of fish biodiversity in Cavally at Ity department of Zouan-Hounien". This work benefited from a support in logistics of the promoters. The authors thank the searchers of Jean Lorougnon Guédé University Daloa (Côte d'Ivoire) who contributed to its realisation. 


\section{References}

[1] Aboua BRD (2012) Développement d'un indice d'intégrité biotique piscicole pour la préservation de la biodiversité du fleuve Bandama. Thèse de Doctorat, Université Félix Houphouët-Boigny, Abidjan, Côte d'Ivoire, 227 p.

[2] Blahoua KG (2013) Diversité biologique et dynamique des populations de monogènes parasites branchiaux des poissons d'eaux douces: cas des monogènes des Cichlidae, Hepsetidae, Mormyridae et des Mochokidae du lac de barrage D'Ayamé I et de la rivière Lobo (Côte d'Ivoire). Thèse de doctorat de l'Université Félix Houphouët-Boigny de Cocody, Abidjan, Côte d'Ivoire, $291 \mathrm{p}$.

[3] Boguhé H (2015) Biologie de la reproduction et exploitation de deux espèces de crevette duGenre Macrobrachium: M. vollenhovenii (Herklots, 1857) et M. macrobrachion (Herklots, 1851) du fleuve Bandama (Côte D'Ivoire). Thèse de doctorat de l'Université Félix Houphouët-Boigny de Cocody, Abidjan, Côte d'Ivoire, 216 p.

[4] Boucharel CLM (2012) Etude du niveau de maîtrise de la sécurité sanitaire des produits halieutiques sénégalais exportés vers l'union européenne. Thèse de doctorat en médecine vétérinaire de l'Université Cheikh Anta Diop de Dakar, Sénégal, $147 \mathrm{p}$.

[5] CSAO (2006) Rapport de réunion. Crevetticulture durable en Afrique de l'Ouest: Opportunités économiques et coopération Sud-Sud. Table ronde régionale Conakry, Guinée: 8-9.

[6] Dajoz R (2000) Précis d'écologie. Dunod, Paris, France, 615 p.

[7] De Grave S, Fransen CHJM (2011) Carideorum catalogus: the recent species of the dendrobranchiate, stenopodidean, procarididean and caridean shrimps (Crustacea: Decapoda). Zoologische Mededelingen Leiden 85 (9): 195589 .

[8] Djiriéoulou KC (2017) Peuplements des crevettes des hydrosystèmes de marais et fluvio-lagunaires du Sud- Est de la Côte d'Ivoire: diversité, structure et croissance des populations. Thèse de Doctorat, Université Félix HouphouëtBoigny de Cocody, Abidjan, Côte d'Ivoire, 196 p.

[9] Djiriéoulou KC, Bamba M, Konan KM, N'Zi KG, Gooré Bi $\mathrm{G}$, and al. (2017) Peuplement de la faune de crevettes de la Forêt des Marais Tanoé-Ehy (Sud-Est de la Côte d'Ivoire). Journal of Applied Biosciences 112: 11100-11110.

[10] Environnement Canada (2010) Paramètres physiques - Eau. http://www.ec.gc.ca/eaudoucefresh...r/default.asp?lang=Fr\&n=61A967F4-1. 02 Mai 2010.

[11] Ettien DZ (2010) Exploitation industrielle des gisements d'or et dynamique spatiale du terroir d'Ity dans l'Ouest de la Côte d'Ivoire. Une étude à base de la télédétection. Revue de Géographie du Laboratoire Leïdi 08: 169-183.

[12] FAO (2008) Vue générale du secteur des pêches nationales de la République de Côte d'Ivoire. pp: 12-13.

[13] Fischer W, Bianchi G, Scott WB (1981) Fiches FAO d'identification des espèces pour les besoins de la pêche. Atlantique centre-est. Zone de pêche 34, 47. Fonds des Nations Unies pour l'Alimentation et l'Agriculture. Ottawa, Canada, $73 \mathrm{p}$.
[14] Fossati O, Mosseron M, Keith P (2002) Distribution and habitat utilization in two Atyid shrimps (Crustacea: Decapoda) in rivers of Nuku-Hiva Island (French Polynesia). Hydrobiologia 472: 197-206.

[15] Girard G (1974) Données fragmentaires sur les régimes hydrologiques en Côte d'Ivoire, $22 \mathrm{p}$.

[16] Girard G, Sircoulon J, Touchebeuf P, Guillaumet LJ, AVENARD MJ, and al. (1971) Le milieu naturel de la Côte d'Ivoire. Mémoires ORSTOM, Paris, France 50: 401 p.

[17] Gooré Bi G (1998) Contribution à l'étude des crevettes d'eau douce de Côte d'Ivoire: systématique, biologie et analyse socioéconomique de la pêche de Macrobrachium vollenhovenii (Herklots 1857) et de M. macrobrachion (Herklots 1851) (Crustacea Decapoda, Palaemonidae) du bassin de la Bia. Thèse de Doctorat 3e cycle, de l'Université de Cocody-Abidjan, Côte d'Ivoire, 145 p.

[18] Gooré Bi G, Kouassi NJ, Thys Van Den Audenaerde FED (2002) Critères pratiques d'identification et peuplement des crevettes (Caridae) de la rivière Bia (Côte d'Ivoire). Bulletin de l'Institut fondamental d'Afrique noire Cheikh Anta Diop, Dakar, Sénégal. pp: 163-186.

[19] Iltis A, Lévêque C (1982) Caractéristiques physico-chimiques des rivières de Côte d'Ivoire. Revue d'Hydrobiologie Tropicale 15 (2): 115-130.

[20] Jeune Afrique, l'intelligent (2002) Côte d'Ivoire, ça commence ! $\mathrm{n}^{\circ} 2176 \mathrm{du} 23$ au 29 septembre. www.jeuneafrique.com

[21] Kamelan TM (2014) Peuplement ichtyologique de quelques hydrosysthèmes de l'espace Taï (Côte d'Ivoire). Thèse de Doctorat en hydrobiologie de 1'Université Félix HouphouëtBoigny, Abidjan, Côte d'Ivoire, 199 p.

[22] Konan KM (2009) Diversité morphologique et génétique des crevettes des genres Atya Leach, 1816 et Macrobrachium Bate, 1868 de Côte d'Ivoire. Thèse de doctorat de l'Université d'Abobo-Adjamé, Côte d'Ivoire: 189 p.

[23] Kouamélan EP, Teugels GG, N'Douba V, Gooré Bi G, Koné T (2003) Fish diversity and its relationships with environmental variables in a West Africanbasin. Hydrobiologia 505: 139-146.

[24] Lévêque C, Dejoux C, Iltis A (1983) Limnologie du fleuve Bandama, Côte d'Ivoire. Hydrobiologia 100: 113-141.

[25] Mahyao AG, Koffi C, Kouassi C, Yapi-Gnaoré V, Tahouo O (2010) La filière crevettes d'eau douce du fleuve Bandama en Côte d'Ivoire, un secteur économique à préserver: in CNRA, Direction des innovations et des systèmes d'information Avec la participation de la direction des programmes de recherche et de l'appui au développement. ISBN, Abidjan, Côte d'Ivoire 978-2-917074-05-3: 12-13.

[26] Mahyao AG, Koffi C, N'Gouan KC, Chia YV (2014) Pêche et commercialisation des crevettes d'eau douce du fleuve Bandama en Côte d'Ivoire. Tropicultura 32 (2): 95-102.

[27] March JG, Pringle CM, Townsend MJ, Wilson AI (2002) Effects of freshwater shrimp assemblages on benthic communities along an altitudinal gradient of a tropical island stream. Freshwater Biology 47 (3): 377-390.

[28] Monod T (1966) Crevettes et crabes des côtes occidentales de l'Afrique. Réunion des spécialistes CSA sur les crustacées, Zanzibar, 1964. Mémoires de l'institut fondamental d'Afrique noire. IFAN-DAKAR: 106-234. 
[29] Monod T (1980) Décapodes. In: DURAND, J. R. \& LEVEQUE, C. (éds.). Flore et faune aquatiques de l'Afrique sahélo-soudanienne. ORSTOM, Paris, Tome I 44: 369-389.

[30] N'Da AS (2015) Biodiversité, structure du peuplement ichtyologique et relations trophiques d'un bassin du Nord de la Côte d'Ivoire: cas de la rivière Bagoé. Thèse de Doctorat de l'Université Félix Houphouët-Boigny, Abidjan, Côte d'Ivoire, $198 \mathrm{p}$.

[31] N'Douba V (2000) Biodiversité des monogènes parasites des poissons d'eau douce de Côte d'Ivoire: cas des poissons des rivières Bia et Agnébi. Thèse de Doctorat d'État de l'Université de Cocody-Abidjan, Côte d'Ivoire, 250 p.

[32] N'Zi KG (2007) Diversité biologique des peuplements de crevettes d'eaux douces de Côte d'Ivoire en relations avec les variables environnementales du milieu. Thèse de Doctorat de l'Université de Cocody, Abidjan, Côte d'Ivoire, 178 p.

[33] N'Zi KG, Gooré BG, Kouamélan EP, Koné T, N'Douba V, and al. (2008) Influence des facteurs environnementaux sur la répartition spatiale des crevettes dans un petit bassin ouest africain: rivière Boubo (Côte d'Ivoire). Tropicultura 26 (1): 17-23.

[34] Naho J (1988) Cycle supergène de l'or en milieu ferralitique. Exemple du gisement d'or d'Ity en Côte d'Ivoire. Thèse de Doctorat de l'Institut National Polytechnique de Lorraine, Nancy, France, 132 p.

[35] OMS (2008) Guidelines for Drinking-water Quality, Third edition, incorporating the first and second Addenda, Recommendations, Geneva, Switzerland 1: $515 \mathrm{p}$.

[36] Painchaud J (1997) La qualité de l'eau des rivières du Québec: état et tendances. Ministère de l'Environnement de la Faune, Direction des écosystèmes aquatiques, $58 \mathrm{p}$.
[37] Parizot M (2008) Contrôle de surveillance de la qualité des masses d'eau souterraine de la Guyane conformément à la Directive Cadre Européenne sur l'eau. BRGM/RP-FR, 100 p.

[38] Powell CB (1982) Fresh and brackish water shrimps of economic important in the Niger Delta. University of Port Harcourt. Present to the second conference of the fisheries society of Nigeria held at Calabar, 24-27 January: 1- 45.

[39] Tchakonté S, Ajeagah G, Diomandé D, Camara AI, Konan $\mathrm{KM}$, and al. (2014) Impact of anthropogenic activities on water quality and Freshwater Shrimps diversityand distribution in five rivers in Douala, Cameroon. Journal of Biodiversity and Environmental Sciences 4 (2): 183-194.

[40] Traoré SG (2013) Risques de contraction des affections à Vibrio sp. et à Paragonimus sp. liés à la consommation des crabes et des crevettes vendus sur les marchés d'Abidjan et de Dabou. Thèse de Doctorat de l'Université Nangui Abrogoua, Abidjan, Côte d'Ivoire, 198 p.

[41] Webber WJ, Stumm W (1963) Mechanism of hydrogen ion buffering in natural waters. Journal American Water Works Association 53: 15-53.

[42] Welcomme RL (1985) River fisheries. FAO fisheries technical paper 262. Rome, Italie $330 \mathrm{p}$.

[43] Yao SS (2006) Contribution à l'étude de la diversité biologique et de l'écologie alimentaire de l'ichtyofaune d'un hydro système ouest africain: Cas du bassin de la Comoe (Côte d'Ivoire). Thèse de Doctorat de l'Université de Cocody, Abidjan, Côte d'Ivoire, $281 \mathrm{p}$.

[44] Yao SS, Kouamélan EP, Koné T, N’Douba V, Gooré Bi G, and al. (2005) Fish communities along environmental gradients within the Comoe River basin, Côte d'Ivoire. African Journal of Aquatic Science 30 (2): 185-194. 